\title{
Improving Agricultural Education Curriculum Through Sea Food Resources at the Tertiary Institutions
}

\author{
Ndem J.U. ${ }^{1},{ }^{2}$ Elom O. ${ }^{2}$, Ochijenu M.A. ${ }^{3}$, Azunku F.N. ${ }^{2}$, Okafor B.N. ${ }^{4}$, Edu C. N. ${ }^{1}$ and Okpara C.M. ${ }^{5}$ \\ 1.Department of Technology and Vocational Education, Ebonyi State University, Abakaliki \\ 2.Department of Agricultural Education Ebonyi State College of Education Ikwo \\ 3.Department of Agricultural Education, Kogi State University, Anyigba \\ 4.Department of Technical Education and Entrepreneurship Studies, Nnamdi Azikiwe University, Awka \\ 5.Department of Vocational and Technical Education, Alex-Ekwueme Federal University, Ndufu-Alike Ikwo
}

\begin{abstract}
.
This work centered on improving Agricultural Education curriculum through sea food resources at the tertiary institutions. The research was conducted in Ebonyi state of Nigeria. The design used for this research was a survey research design. The research had five specific purposes and five research questions. The collection of data used for the study was done using questionnaire as the instrument. The questionnaire contained 50 items. The questionnaire was validated by experts in agricultural Education, measurement and evaluation and curriculum. The reliability of the instrument was determined by carrying out a pilot test. The data collected from the pilot test was analyzed using cronbach alpha which gave a reliability coefficient of 0.812 . The data collected were subjected to analysis using statistical mean and standard deviation. The outcome of the analysis of the data revealed that the concepts of the sea food resources should be included in the agricultural education curriculum at the tertiary institutions, the management skills in sea food resources, the harvesting techniques of sea food resources, the processing, preservation and storage techniques of sea food resources and the distribution and marketing of sea food resources should be included in the agricultural education curriculum at the tertiary institutions. On the basis of the findings, the researchers recommended that the ministry of education, the institutions offering agricultural education and the national university commission (NUC) should include the findings of this research in the curriculum of agricultural education.
\end{abstract}

Keywords: Agriculture; Education; Curriculum; food;resources;tertiary;institutions.

DOI: $10.7176 / \mathrm{JEP} / 11-35-04$

Publication date: December $31^{\text {st }} 2020$

\section{Introduction}

Agricultural education is one of the basic tools for achieving food security and economic advancement in Nigeria. Ndem, (2010) defines Agricultural education as an aspect of educational process that prepares individuals for practical skills and basic scientific knowledge required for agricultural production. Usman \& Sulaman (2000) in Daitan (1985) opined that Agricultural education also involves the inculcation of the right attitudes, values, habits, abilities, understanding, competences, scholarship, leadership, co-operation and citizenship needed for entry into agricultural occupation. Simply put, agricultural education is that aspect of vocational education that is concerned with the development of agricultural production skills and competencies in the learners. Agricultural education is taught at the tertiary institutions with the aim of producing graduates with the necessary skills, knowledge and techniques in crop and animal production, processing, marketing as well as the management of land and other resources for efficient production. include:

The overall objectives of agricultural education according to the Federal Republic of Nigeria (FRN), (2013)

1. To develop skills and basic scientific knowledge and competences required in agricultural production.

2. To develop an understanding and appreciation of career opportunities in agricultural occupation and the preparations required to progress in production agriculture, agricultural business and other careers in agriculture.

3. To develop the ability to secure satisfaction in placement and advancement in agricultural occupation through programmes on continuing education.

4. To develop leadership qualities, attitudes, thrifts, scholarships, co-operations, citizenship and patriotism by participating in experiences and activities of agricultural programmes.

5. To develop competences required by individuals engaged in agriculture.

6. To develop practical skills and competencies in agricultural research. An individual that is fully equipped as an agricultural educator will not just be self reliant or create job opportunities for others but can also teach and undertake research to advance the field of agriculture. However, there is need to improve the curriculum of agricultural education in order to accommodate other attractive and untapped aspects of agriculture like sea food resources at the tertiary institution level. This will make the curriculum more comprehensive, rich and attractive. There is no generally agreed upon definition of the term curriculum. Some influencial definitions 
that combines various elements to describe curriculum as follows: Ownuka, (1981) defined curriculum as the total learning experiences with which the school deals in educating the young people. Tanner \& Tanner, (1975) defined curriculum as the planned and guided learning experiences and intended learning outcomes, formulated through systematic reconstruction of knowledge and experience under the auspices of the school for the learners' continuous and willful growth in personal, and social competence.

Farrant, (1981) defines curriculum as all that is taught in school including the time tabled subjects and all those aspects of it's life that exercise an influence on the life of the children. Curriculum in the context of this study therefore is the totality of all learning experiences, planned and guided inside or outside formal school system through which learners acquire skills, knowledge, attitudes and competencies necessary to hence a productive and self-reliant lives, secure, maintain or advance in their chosen occupation. Considering the overall objectives of agricultural education by FRN (2013), the curriculum of agriculture education can be boosted through sea food resources. Sea food is referred to as any form of sea life that is regarded as food by humans. It is extended to all forms of aquatic life that is used as food by man e.g fish, shell fish, aquatic mammals, aquatic reptiles and aquatic plants Sea food resources also include; fish (Codfish, mackerel, sardine, cart fish tilapia etc), shell fish such as mollusks (clams, oysters, mussels, octopods, squids etc), Crustaceans (shrimps, crabs, crayfish, lobsters) and echinoderms (star fish, sea cucumber), sea mammals (dolphins whales) sea reptiles (turtles) and sea plants (sea weeds and microphytes which are used as food for man, feed for animals and other fishes as well as other economic uses.

Sea food resources also ranged from fish, shell fish (mollusks, crustacean, echinoderms) aquatic mammals, aquatic reptiles serve not only as food for man but constitute the major source of protein in almost all households in Nigeria and across the world, Example; of sea food are crayfish, stock fish, dry fish and the famous ice fish. There is barely any household that cooks without using at least one of the sea food resources indicated above on daily basis. They serve as sources of income and means of livelihood especially those living in river rine areas who depend on fishing or fish farming as their occupation and source of income. Other individuals engage in aquacultures, fish preservation and processing as business or occupation. The by- products from sea food resources serve as feeds for other fish and animals. Sea food are important sources of oil such as cod fish oil, they are rich in omega-3 oil, they serve as raw materials used in the manufacture of drugs such as Spirulina tablets. The consumption of sea food rich in oil like omega- 3 fatty acid promotes heart health, maintain eye sight, boost brain power, enhances foetal growth and development of pregnancy in women and improve immune systems such as reduction of symptoms of asthma and other allergies. Since sea food resources is one of the aspects of agriculture, it is necessary that sea food resources should be included in the agricultural education curriculum. This will keep students of agricultural education abreast of the various aspects and opportunities in sea food resources through formal education, increase their awareness and knowledge about the content of sea food resources, techniques and competencies required in harnessing sea foods management techniques, preservation and processing technique required in sea foods It is on this bases that this work is designed to determine the strategies for improving the curriculum of agricultural education through sea food resources.

\section{Statement of the Problem}

The high rate of unemployment of Nigerian graduates, increase in the number of school dropouts as well as other social vices are clear indications that Nigerian education has not been able to meet it's objectives of producing graduates who will be productive self reliant, wealth creators and job providers. Unfortunately, sea resources is one of the promising aspect of agriculture education that has not be fully utilized. The inclusion of sea food resources as an aspect of agricultural education curriculum will not only help to reduce the rate of unemployment, school dropouts and social vices but will also increase the knowledge, skills, techniques and competencies of agricultural educationgraduates in sea food resources as well as increased job and career opportunities.

\section{Purpose of the Study}

The main purpose of this study was to determine the aspects of sea food resources that could be included in the curriculum of agriculture education at the tertiary institutions .

Specifically, the study sought to determine;

1. Inclusion of the concept of sea resources in the curriculum of agricultural education at the tertiary institutions

2. Inclusion of the management skills in sea resources in the curriculum of agricultural education at the tertiary institutions

3. Inclusion of the harvesting techniques of sea food resources in the curriculum of agricultural education at the tertiary institutions

4. Inclusion of processing, preservation and storage skills of seafood resources in the curriculum of agricultural education at the tertiary institutions.

5. Inclusion of marketing and distribution techniques of sea foods in the curriculum of agricultural education curriculum at the tertiary institutions. 
Research Questions

The following research questions guided the study

1. What are the concepts of sea foods resources that should be included in the agricultural education curriculum at the tertiary institutions?

2. What are the management techniques in sea foods resources that should be included in the agricultural education curriculum at the tertiary institutions?

3. What are the harvesting techniques in sea food resources to be included in the agricultural education curriculum at the tertiary institutions?

4. What are the processing, preservation and storage skills in sea food resources that should be included in the agricultural education curriculum at the tertiary institutions?

5. What are the marketing and distribution techniques in sea food resources to be included in the agricultural education curriculum at the tertiary institutions

\section{Methodology}

This research used descriptive survey method in carrying out the research. Five specific purposes of study and questions were used to carry out this study. Also five null hypotheses were tested on the course of this work. The study used 53 experts in agricultural education, micro livestock farmers and curriculum experts drawn from the five tertiary institutions in Ebonyi State of Nigeria as the sample for the study. Researchers' self structured questionnaire served as the instrument utilized for the gathering of data for the work. The instrument was subjected to critical validation by the agricultural education, measurement and evaluation and curriculum experts. The instrument was field tried tested and the data from the field trial were analyzed using cronbach alpha with the reliability coefficient of 0.812 . The data gathered were subjected to analysis using mean and standard deviation statistics for the research questions. The decision on the research questions was based on 2.50 which was adopted as the bench mark for decision. This implies that any item in the instrument which scored the mean range of 2.50 and above was adopted as the item to be included in the agricultural education curriculum while any item that scored below 2.50 was regarded as an item that should not be included in the agricultural education curriculum at the tertiary institution.

Research Question 1

What are the concepts of sea food resources that should be included in the agricultural education curriculum at the tertiary institution?

Table 1: Mean and Standard Deviation of the respondents on the concepts of sea food resources to be included in the agricultural education curriculum at the tertiary institutions $\mathrm{N}=53$

\begin{tabular}{|c|c|c|c|c|}
\hline $\mathbf{S} / \mathbf{N}$ & ITEMS & $\overline{\mathbf{X}}$ & SD & DECISION \\
\hline 1 & Sea food resources means all the aquatic organisms in the sea. & 3.26 & 0.85 & Agree \\
\hline 2. & Sea food resources provides employment to people & 3.33 & 0.75 & Agree \\
\hline 3. & Sea food resources are rich sources of protein & 3.24 & 0.85 & Agree \\
\hline 4 & Sea food resources are good source of foreign exchange & 3.20 & 0.76 & Agree \\
\hline 5 & $\begin{array}{l}\text { Inclusion of sea food resources enriches the agricultural education } \\
\text { curriculum }\end{array}$ & 3.24 & 0.75 & Agree \\
\hline 6 & $\begin{array}{l}\text { Sea food resources are of many classes such as crustaceans, molucs fish and } \\
\text { so }\end{array}$ & & & \\
\hline & many others & 3.09 & 0.92 & Agree \\
\hline 7 & Sea food resources has no economic benefit & 1.62 & 0.65 & Disagree \\
\hline 8 & $\begin{array}{l}\text { Inclusion of sea food resources in the curriculum of agricultural } \\
\text { education overloads the curriculum }\end{array}$ & 1.90 & 0.98 & Disagr \\
\hline 9 & Sea food resources contain less protein than other livestock & 1.81 & 0.94 & Disagree \\
\hline 10 & $\begin{array}{l}\text { Sea food resources may not generate employment opportunities individuals } \\
\text { Grand Mean }\end{array}$ & $\begin{array}{l}1.67 \\
2.63\end{array}$ & 0.82 & Disagree \\
\hline
\end{tabular}

Table 1 reveals that items 1-6 had their mean scores above the criterion points of 2.50 and the respondents identified 6 items on the concept of sea food resources that should be included in the curriculum of agricultural education at the tertiary institutions. The standard deviation of the respondents ranged between $0.65-0.98$. This indicates that the opinions of the respondents did not deviate for from the central mean.

\section{Research Question 2}

What are the management skills in sea food resources that should be included in the curriculum of agricultural education at the tertiary institutions? 
Table 2: Mean and Standard Deviation of the respondents on the management skills in sea food resource for inclusion in the agricultural education curriculum at the tertiary institutions $N=53$

\begin{tabular}{|l|llll|}
\hline S/N & ITEMS: Statement Ability To: & $\overline{\mathbf{X}}$ & $\mathbf{S D}$ & DECISION \\
1 & Control desert encroachment & 3.00 & 0.98 & Agree \\
2. & Manage the climate change to minimize the drying of the rivers and oceans & 2.98 & 1.09 & Agree \\
3. & Avoid the dumping of toxic materials in the water bodies & 3.20 & 0.84 & Agree \\
4 & Fertilize the micro-plantons in the water for feeding of the sea foods & 3.16 & 0.84 & Agree \\
5 & Dump appropriate feeds in the water river, sea for the feeding of the fishes & & & \\
& and other aquatic organisms & 3.07 & 0.91 & Agree \\
6 & Dumping of toxic waste in the river and seas & 1.64 & 0.87 & Disagree \\
7 & Polluting of the sea and water bodies with individual wastes & 1.73 & 1.02 & Disagree \\
8 & Allowing crude oil to spill into the rivers & 1.60 & 0.76 & Disagree \\
9 & Checking the spill of industrial wastes not to enter into the river & 3.07 & 0.91 & Agree \\
10 & Prevention of crude oil from entering the water bodies & 3.18 & 0.87 & Agree \\
& Grand Mean & $\mathbf{2 . 6 6}$ & & \\
\hline
\end{tabular}

Table 2 shows that items 1,2,3,4,5,9 and 10 had their mean scores above the cutoff point of 2.50 . This implies that the respondents identified 7 management skills in sea food resources that should be included in the curriculum of the agricultural education curriculum at the tertiary institutions. The standard deviations of the respondents ranged from $0.76-1.09$. Therefore, the mean deviation of the respondents was not far from the central mean.

\section{Research Question 3}

What are the techniques of harvesting of sea food resources for inclusion in the agricultural education curriculum at the tertiary institutions?

Table 3: Mean and standard deviation of the respondents on the techniques of harvesting of sea food resources for inclusion in the agricultural education curriculum at the tertiary institutions $N=53$

\begin{tabular}{|c|c|c|c|c|}
\hline $\mathbf{S} / \mathbf{N}$ & ITEMS STATEMENT & $\overline{\overline{\mathbf{x}}}$ & SD & DECISION \\
\hline 1 & Harvesting the matured sea food resources only & 3.15 & 0.84 & Agree \\
\hline 2. & Harvesting of both the matured and young sea food resources always & 1.64 & 0.70 & Disagree \\
\hline 3. & Use of chemicals to harvest fish and other aquatic organisms & 1.64 & 0.77 & Disagree \\
\hline 4 & $\begin{array}{l}\text { Avoidance of the use of chemical techniques in harvesting of fish and other } \\
\text { aquatic organisms. }\end{array}$ & 3.24 & 0.91 & Agree \\
\hline 5 & Use of explosives to harvest fish and other sea foods & 1.67 & 0.75 & Disagree \\
\hline 6 & Use of poisons to harvest fish and other sea foods & 1.50 & 0.66 & Disagree \\
\hline 7 & $\begin{array}{l}\text { Avoidance of the use of poisons in harvesting fish and other sea } \\
\text { foods. }\end{array}$ & 3.49 & 0.66 & Agree \\
\hline 8 & Harvesting of fishes and other sea foods with hooks & 3.52 & 0.66 & Agree \\
\hline 9 & Harvesting fishes and other sea foods with net & 3.49 & 0.77 & Agree \\
\hline 10 & $\begin{array}{l}\text { Harvesting fishes and other sea foods with arrow and spear } \\
\text { Grand Mean }\end{array}$ & $\begin{array}{l}3.05 \\
\mathbf{2 . 6 3}\end{array}$ & 0.94 & Agree \\
\hline
\end{tabular}

Table 3 identified 6 items on the harvesting techniques of sea food resources to be included in the curriculum of the tertiary institution with their mean scores between 3.05 and 3.52 which are above the cut of point of 2.50 . The standard deviation ranged between 0.66 to 0.94 . This shows that the mean responses did not deviate far from the central mean.

\section{Research Question 4}

What are the appropriate processing, preservation and storage techniques for inclusion in the agricultural education curriculum at the tertiary institutions?

Table 4: Mean and Standard Deviation of the respondents on the processing, preservation and storage techniques for inclusion in the agricultural education curriculum at the tertiary institutions $N=53$

\begin{tabular}{|c|c|c|c|c|}
\hline $\mathbf{S} / \mathbf{N}$ & ITEMS STATEMENT & $\overline{\mathbf{x}}$ & SD & DECISION \\
\hline 1 & Use of refrigerators to preserve sea food resources & 3.11 & 0.98 & Agree \\
\hline 2. & Use of cold room to preserve and store sea foods & 3.35 & 0.81 & Agree \\
\hline 3. & Use of chemicals to preserve sea foods & 1.62 & 0.73 & Disagree \\
\hline 4 & Canning method to store sea foods & 3.52 & 0.69 & Agree \\
\hline 5 & Drying of the fish and harvested aquatic resources in the sun & 3.03 & 0.97 & Agree \\
\hline 6 & Drying of the harvested sea foods with electricity system & 3.41 & 0.77 & Agree \\
\hline 7 & Washing and cleaning of the harvested sea foods & 2.92 & 1.05 & Agree \\
\hline 8 & Addition of flavor to the sea food during processing before storage & 3.22 & 0.82 & Agree \\
\hline 9 & Addition of food additives to the sea foods during processing & 3.43 & 0.77 & Agree \\
\hline \multirow[t]{2}{*}{10} & Storing of processed sea foods in tins and sacs & 3.03 & 0.91 & Agree \\
\hline & Grand Mean & 3.06 & & \\
\hline
\end{tabular}


Table 4 identified 9 items on the processing, preservation and storage of sea food resources to be included in the curriculum of agricultural education at the tertiary institutions with their mean scores which ranged between 0.69 to 1.05 . This is an indication that the mean responses did not deviate far from the central mean.

\section{Research Question 5}

What are the marketing and distribution techniques of sea food resources for inclusion in the agricultural education curriculum at the tertiary institutions?

Table 5: Mean and standard deviation of the respondents on the techniques of marketing and distribution of sea food resources for inclusion in the agricultural education curriculum at the tertiary institution $\mathrm{N}=$ 53

\begin{tabular}{|l|lccc|}
\hline S/N & ITEMS STATEMENT & $\overline{\mathbf{X}}$ & SD & DECISION \\
1 & Identification of profitable markets & 2.98 & 1.07 & agree \\
2. & Distributing sea food resources to middlemen whole sale marketers & 3.50 & 0.60 & agree \\
3. & Selling the sea foods to restaurants & 3.20 & 0.90 & agree \\
4 & Selling the sea foods to members of neighborhoods' & 2.94 & 1.08 & agree \\
5 & Selling the sea foods by exporting to foreign countries & 2.88 & 1.08 & agree \\
6 & Distributing and selling of sea foods to individual consumers & 2.67 & 0.99 & agree \\
7 & Marketing the sea food products to retailers & 2.75 & 1.15 & agree \\
8 & Marketing the sea food products to urban centres markets & 3.32 & 0.89 & agree \\
9 & Marketing and distributing the sea food products to rural markets & 1.60 & 0.76 & Disagree \\
10 & Marketing the sea food products to fish hawkers & 1.79 & 0.88 & Disagree \\
& Grand Mean & $\mathbf{2 . 7 6}$ & & \\
\hline
\end{tabular}

Table 5, identified 8 items on the distribution and marketing of sea food resources to be included in the curriculum of agricultural education curriculum at the tertiary institutions with their mean scores ranging between 2.20 - to 3.50 , and the standard deviation ranging from $0.60-1.15$. This shows that the mean responses did not deviate far from the central mean.

\section{Major Findings}

Based on the analysis of the data collected, below are the finds major

1. sixconcepts of sea food resources should be included in the curriculum of agricultural education at the tertiary institutions such as provision of seven employment and source of foreign exchange among others

2. Seven management skills in sea food resources should be included in the curriculum of agricultural education at the tertiary institutions such as feeding the fishes and other aquatic organisms in the water body among others.

3. Six techniques of harvesting of sea food resources should be included in the curriculum of agricultural education at the tertiary institutions such as harvesting only the matured sea foods among others.

4. Nine processing, preservation and storage techniques of sea food resources should be included in the curriculum of agricultural education at the tertiary institutions such as using cold room to store sea food resources among others.

5. Eight distribution and marketing techniques should be included in the agricultural education curriculum at the tertiary institutions such as identifying the consumers and profitable markets of sea food resources among other.

\section{Discussion of Findings}

The discussion of the findings is based on the five basic purposes. The findings of the study reveals that the concepts of sea food resources should be included in the curriculum of agricultural education at the tertiary institutions. This finding supports the work of Tanner, and Tanner (1975) who reported that the curriculum content of any curriculum must be rich enough to cover the concepts and scope of any subject matter or course. Furthermore, the finding says that management skills in sea food resources should be included in the curriculum of agricultural education. This finding supports Mgbeahuruike (2001) who reported that the management of any enterprise is essential in the achievement of the goals and objectives of the enterprise. He further explained that management skills are required by managers in order to manage effectively additionally, Osula (2000) explained that the acquisition of management skills is the first step to success in the goal achievement of any organizations. Furthermore, the work revealed that harvesting techniques of sea food resources should be included in the curriculumof agricultural education. This finding agrees with the work of Olaitan (1998) who stated that in agricultural production harvesting and the techniques of harvesting must be considered in order to avoid waste. He further asserted that if crops or live stocks like fish in the pond are not harvested at the right time with the appropriate techniques, the farmer is bound to encounter heavy loss and more especially, in the case of the fish cannibalism may result .He advocates that harvesting farm produce with the appropriate techniques at the appropriate period should be adopted by farmers for profit maximization, reduction of wastes and avoidance of 
cannibalism

The finding of the research also shows that the processing, preservation and storage of sea food resources should be included in the curriculum of agricultural education at the tertiary institutions. This finding supports the work of Ndem (2010) who explained that processing, preservation and storage of agricultural products add value to the commodities. He further stressed that if it is possible, farmers should always process, preserve and properly store their farm products which will attract more income during the off season, thereby maximizing profits.

Finally, this research revealed that marketing and distribution techniques of sea food resources of should be included in the curriculum of agricultural education curriculum at the tertiary institutions. This finding supports the work of Makaham (1997) who reported that production is incomplete, until the goods and services reach the appropriate consumers. He further remarked that the distribution and marketing of farm products should always be carried out to ensure that the farm products reach to the consumers where such commodities are not produced . Therefore, the inclusion of the marketing and distribution skills in the agricultural education curriculum is commendable.

\section{Conclusion}

A sea food resource is one of the vital sectors in agriculture and agricultural education which has not been given serious attention in the curriculum of agricultural education at the tertiary institutions. A sea food resource has great potential in the advancement of agriculture and nation and international development. This research has come out with those aspects of sea food resources that has been identifies to be included in the curriculum of agricultural education at the tertiary institutions in order to further enrich and improve agricultural education at the tertiary institutions.

\section{Recommendations}

Based on the findings of the work, the researchers recommended the following.

The curriculum planners in collaboration with the institutions offering agricultural education to include;

1. The concept of sea food resources

2. The management skills in sea food resources,

3. The techniques of harvesting sea foods

4. The processing preservation and storage of sea foods and

5. The marketing and distribution of sea foods in the curriculum of agricultural education at the tertiary institutions.

\section{Acknowledgements}

The authors wish to acknowledge the Ebonyi State Agricultural Development Project for providing the vital data used in this work. Also, the analyst and typist who typeset the manuscript are appreciated.

\section{REFERENCES}

Farrant, J. S. (1981) Principles and Practice of Education. London: Morrison and Gibb Ltd. FRN (2013) National Policy on Education. Abuja: NERDC.

Makaham, J.P (1997). Agricultural Economics and Marketing in the Tropics. London: Longman Group Ltd.

Mgbeahuruke, M.N. (2001). Skill improvement Needs of Agricultural Science Teachers for Effective Management of School Farm in Secondary Schools in Imo State. Department of Vocational Teacher Education, University of Nigeria, Nsukka.

Ndem, J.U. (2010). Vocational Agricultural Education: An Investment for Achieving Food Security in Nigeria. International Technology Research Journal 1(1) 117-122.

Ogunu, M. (2001). Introduction to Educational Management. Benin City: Ambik Press.

Olaitan, S.O (1985). Competencies Based professional improvement Needs of Agricultural Science Teachers in Secondary Schools: The Ondo State Experience, Lagos: Macmillan Publishers.

Onwuka, U. (1981) Curriculum Development for Africa.Onitsha Africana FEP.

Osuala, E. C. (2000). Business Management Onitsha: Cape Publishers International Ltd.

Payne, F.L (1992) Operation Management. New York: Toronto; John Willey and Sons.

Tanner, D \& Tanner, L.N (1975) Curriculum Development Theory into Practice. London: Macmillan Publishing CO. Inc.

Usman, B. A. \& Suleman, A. I. (2000). Strategies for teaching of Agricultural Education at the Colleges of Education. Journal of Association of Agricultural Education Teachers of Nigeria. 2(1) 63-79. 